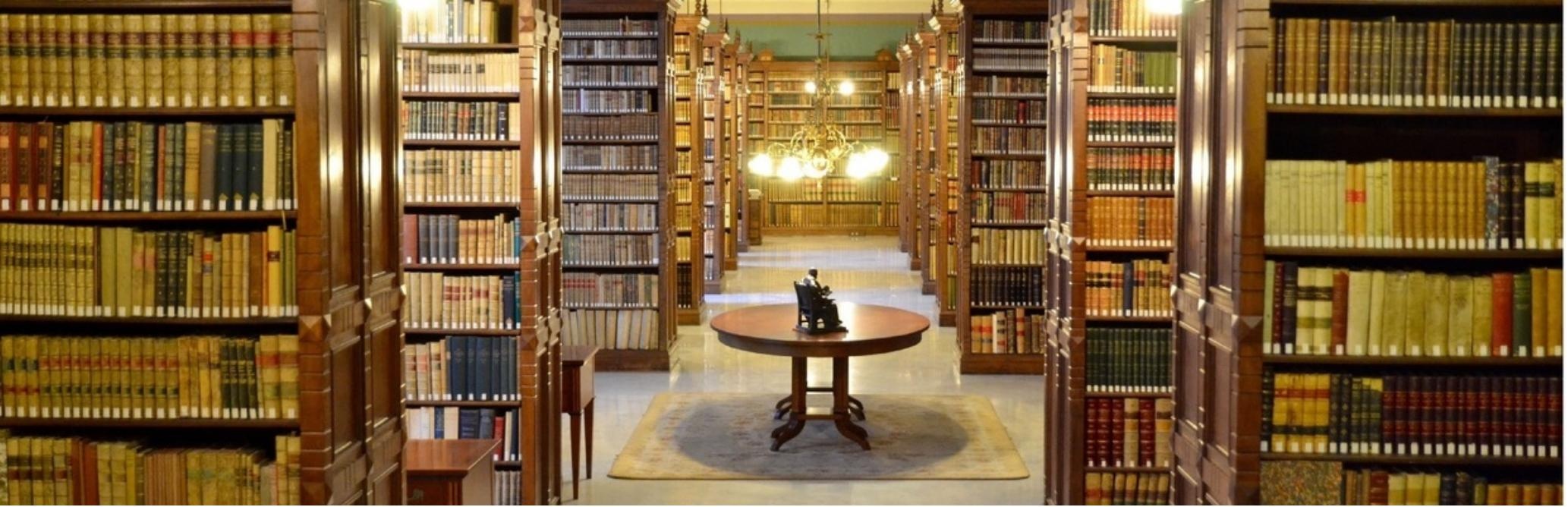

\title{
Editorial Volume 7, Issue 6
}

$\begin{aligned} \text { Authors: } & \text { Silke Masullo } \\ \text { Submitted: } & \text { 8. January } 2021 \\ \text { Published: } & 8 \text {. January } 2021 \\ \text { Volume: } & 7 \\ \text { Issue: } & 6 \\ \text { Affiliation: } & \text { Josha Journal, Freiburg, Germany } \\ \text { Languages: } & \text { English } \\ \text { Keywords: } & \text { Editorial, JOSHA Journal, 2020/21 November 3rd-January 8th } \\ \text { Categories: } & \text { News and Views } \\ \text { DOI: } & 10.17160 / \text { josha.7.6.731 }\end{aligned}$

Abstract:

The Journal of Sciences, Humanities and Arts wants to move on in 2021 to provide you many more articles in your favorite research fields and further exciting artworks. The whole Journal-Team wishes you a happy new year 2021!

JOSHA

josha.org
Journal of Science,

Humanities and Arts

JOSHA is a service that helps scholars, researchers, and students discover, use, and build upon a wide range of content 


\author{
Editorial \\ Volume 7, Issue 6
}

\title{
Happy new year 2021
}

For most of us, the year 2020 did not go as we had imagined and will remain in our memories for a long time. Two things have become apparent: firstly, constant support for scientists is more important than ever, especially when we are faced with new problems in the medical field. Secondly, digitalisation has taken another giant step in 2020 . We see this as confirmation that all knowledge and research have their justification, that it must be freely accessible and that scientists must be supported. With the Journal of Sciences, Humanities and Arts, the basics for making research visible and for digitalisation are existent. We want to move on in 2021 to provide you many more articles in your favorite research fields and further exciting artworks.

Now we hope you enjoy reading the journal.

The whole Journal-Team wishes you a happy new year 2021!

Dr. Stephan Seiler, Vice President International Academy of Sciences, Humanities and Arts

\section{Volume 7, Issue 6}

Konrad Förstner, Peter Kraker, Gerhard Lauer, Claudia Müller-Birn, Felix Schönbrodt, Renke Siems, Björn Brembs: Auf einmal Laborratte - Suddenly a laboratory Rat

Joachim-Friedrich Kapp: Menschenrechte, Institutionen des Staates. Die zukünftige Gesellschaftsordnung Human Rights, Governmental Institutions, and the Future of Society

Heiner Roetz: Unter DEAlern - Amongst DEALers

Gayatri Sunkad: The Empowerment of Women and Children in India

Joachim-Friedrich Kapp: Die Deutsche Sprache im Zeitalter der Aufklärung - The German Language in the Age of Enlightenment

Pablo Adrián Gonzalez: Aprender de hongos - Learn from Mushrooms

Franziska Buttgereit: Breast Implant IIIness (BII)

Blerim Lutolli: The Complexity of the Venturi Contradiction

Joachim-Friedrich Kapp: Ist Gott Schöpfer und Regierer, nur Schöpfer oder beides nicht? Was kann man überhaupt über ihn wissen? Is God Creator and Ruler, only Creator or none of both? What can one even know about him?

Olayide O. Oladeji: External Actors and Democratization Process in Nigeria's Fourth Republic: The Case of the United States of America 